\title{
The Prevalence of "MEFV" Gene Mutations in Rheumatoid Arthritis Patients Inhabiting the Van Province and Surroundings
}

\section{Van ve Çevresinde Yașayan Romatoid Artrit Hastalarında MEFV Gen Mutasyonlarının Prevalansı}

\author{
Halil ÖZKOL ${ }^{1}$, İbrahim Halil YILDIRIM², Yasin TÜLÜCE', Levent EDiZ3, Veysel DELEN, Elif GÜLCÜ \\ ${ }^{1}$ Department of Medical Biology, Yüzüncü Yıl University Faculty of Medicine, Van, Turkey \\ ${ }^{2}$ Department of Genetics, Dicle University Faculty of Veterinary, Diyarbakır, Turkey \\ ${ }^{3}$ Department of Physical Medicine and Rehabilitation, Yüzüncü Yıl University Faculty of Medicine, Van, Turkey
}

\begin{abstract}
Objective: An inhibitory protein of inflammation pyrin/marenostrin is encoded by the Mediterranean fever (MEFV) gene. Mutations of this gene are known to cause familial Mediterranean fever (FMF) disease. A relation between mutations of the MEFV gene and rheumatic diseases was also suggested. The aim of the present study was to investigate the frequency of four common mutations of the MEFV gene in 110 rheumatoid arthritis (RA) patients and 98 healthy controls (HC) inhabiting a region of eastern Turkey.

Material and Methods: DNA extraction was realized by salting out method from peripheral blood lymphocytes of all subjects included in the study. Polymerase chain reactions (PCR) amplification of exon 10 was performed by the appropriate primers, and single-nucleotide polymorphisms (SNPs) were detected by specific restriction endonucleases recognizing the mutational DNA or wild-type DNA regions.

Results: Mutation frequency of RA patients was higher than in $\mathrm{HC}$, but this result was not statistically significant $(p>0.05)$.

Conclusion: The MEFV mutation rate of RA patients living in eastern Turkey was not significantly different from HC. Further studies are needed to investigate other gene mutations that may affect RA etiopathogenesis. Key Words: Rheumatoid arthritis, Mediterranean fever, pyrin, singlenucleotide polymorphisms
\end{abstract}

Özet

Amaç: Enflamasyonu inhibe edici bir protein olan pyrin/marenostrin, Ailevi Akdeniz ateşi (AAA) geni tarafından kodlanır. Bu gendeki mutasyonların, AAA hastalığına sebep olduğu bilinir. Akdeniz ateşi geninin mutasyonları ile romatolojik hastalıklar arasında da bir ilişki olduğu ileri sürülmüştür. Bu çalışmanın amacı AAA geninin en sık rastlanan 4 mutasyonunun frekansını, Türkiye'nin doğusunda yaşayan 110 romatoid artrit (RA) hastasında ve 98 sağlıkı kontrol (SK) bireylerinde araştırmaktır.

Gereç ve Yöntemler: DNA eldesi, çalışmaya dahil edilen bütün bireylerin periferal lenfositlerinden "salting out" metoduyla gerçekleştirilmiştir. Ekzon $10^{\prime}$ un polymerase chain reactions (PCR) amplifikasyonu uygun primerler yardımıyla yapılmış ve tek nükleotid polimorfizimleri (TNP) mutasyonel veya yabanıl tip DNA bölgelerini tanıyan spesifik restriksiyon endonükleazlar yardımıyla belirlenmiş̧ir.

Bulgular: Bu çalışmada, romatoid artrit hastalarının mutasyon frekansı, SK bireylerinden daha yüksek bulundu. Ancak, bu sonuç istatistiksel olarak anlamlı değildi $(p>0,05)$.

Sonuç: Türkiye'nin doğusunda yaşayan RA hastalarındaki AAA mutasyon oranı, SK bireylerinden anlamlı derecede farklı değildi. Romatoid artrit etyopatogenezinde etkili olabilecek diğer gen mutasyonlarını araştırmak için yeni çalışmalara ihtiyaç bulunmaktadır.

Anahtar Kelimeler: Romatoid artrit, Akdeniz ateşi, pyrin, tek nükleotid polimorfizimleri 


\section{Introduction}

Rheumatoid arthritis (RA) is a chronic and inflammatory disease characterized by synovial inflammation that causes cartilage and bone destruction as well as systemic defects, including cardiovascular, pulmonary, psychological, and skeletal disorders $(1,2)$. Symmetrically affected joints and inflammation are the main symptoms of RA, separating it from other forms of arthritis (3). The etiology of RA is unclear, but it has been suggested that the inflammatory and autoimmune activities lead to destruction of joint surfaces. This destruction restricts the joint motion and causes some deformities $(1,4)$.

Pyrin/marenostrin protein is involved in the anti-inflammatory pathway (5). Mutated forms of pyrin are frequently found in familial Mediterranean fever (FMF) patients. The gene encoding pyrin is known as Mediterranean fever (MEFV) gene (6). Until the discovery of this gene, the function of pyrin was unknown (7). Later, it was found that pyrin was upregulated by anti-inflammatory signals, such as IL-10 and IL-4 (8). The function of pyrin is thought to inhibit the inflammation process by binding to apoptosis-associated speck-like (ASC) protein with its pyrin domain (PYD) and reduce the activity of caspase-1 (7). When non-functional or low levels of pyrin are expressed, caspase 1 activates and leads to stimulation of IL-1 $\beta$, which causes inflammation (7). Increased or inhibited inflammasome activity may be the molecular basis of the symptoms associated with pyrinrelated autoinflammatory disorders, like RA.

In the current study, we aimed to determine the four most common mutations in exon 10 of the MEFV gene, which are responsible for more than $80 \%$ of FMF alleles of FMF disease, in RA patients and healthy controls $(\mathrm{HC})$ inhabiting a region of eastern Turkey.

\section{Material and Methods}

The blood samples were collected from 110 RA patients (42 males and 68 females) and 98 age-/sex-matched HC (42 males and 56 females). Patients with other inflammatory, autoimmune, acute, or chronic infectious diseases and diabetes mellitus were excluded from the study. Mean age of the RA patients and $\mathrm{HC}$ was $41 \pm 15.21$ and $42 \pm 13.89$ years, respectively. DNA extraction was realized by salting out method from peripheral blood lymphocytes (9). The oligonucleotide primers were selected from an earlier study (10) and optimized for appropriate annealing temperatures in our laboratory. Polymerase chain reactions (PCRs) were performed according to these annealing temperatures in a final volume of $25 \mu \mathrm{L}$. Genotyping was performed by restriction enzyme digestion of amplicons according to protocols provided by the supplier of the enzymes. The four most common observed mutations (M680I, M694V, M694I, and V726A) of the MEFV gene were analyzed in this study. The study was approved by the local ethics committee of Yüzüncü Yıl University Faculty of Medicine, and the patients' written informed consent was obtained.

The restriction enzymes and expected fragment sizes after the digestion are given in Table 1. Digested fragments were monitored in agarose gels at concentrations of between $3 \%$ and $4 \%$.

\section{Statistical Analysis}

Descriptive statistics were expressed as count and percent. Chi-square test was used to test the significance of the distribution of mutations between RA patients and HC. Statistical significance levels were considered as 5\%, and the Statistical Package for the Social Sciences (SPSS) (ver. 13) statistical program was used for all statistical computations.

\section{Results}

The mutation frequencies of RA patients and HC are summarized in Table 2. 12.9\% of RA patients were heterozygous for the four most common MEFV gene mutations. The total mutation frequency of HC was $9.7 \%$. Statistical analyses showed that there was no statistically significant difference between the results obtained from RA patients and HC ( $p>0.05)$. Although no statistically significant difference was found between all normal and mutant genotypes in both patient and control groups, the frequency of the mutant genotype was higher in RA patients than HC (Table 3). The observed frequencies of genotypes in RA patients and $\mathrm{HC}$ were consistent with the expected frequencies according to the Hardy-Weinberg law.

\section{Discussion}

In this study, we aimed to determine the mutation frequency of the MEFV gene in RA patients by examining the status of the four most common mutations of this gene. For this purpose, the M680I, M694V, M694I, and V726A mutations were investigated in DNA samples isolated from peripheral blood of $110 \mathrm{RA}$ patients and $98 \mathrm{HC}$. In the design stage of this study, we expected statistically significant results between RA patients and $\mathrm{HC}$ in terms of these mutations, due to the role of inflammation in the etiology of RA and also the role the MEFV gene product, pyrin, in anti-inflammatory processes (11). After laboratory analysis, we detected a mutation frequency of the MEFV gene of $12.9 \%$ and $9.7 \%$ in RA patients and $\mathrm{HC}$, respectively. Although our data supported that the mutation rate of this gene is higher in RA patients than $\mathrm{HC}$, this result was not significantly different.

In a similar study performed by Rabinovich et al. (12) conducted in totally 98 Israeli RA patients, consisting of 74 females and 24 males, mutations M694V and V726A, which we also determined in the current study, were investigated. Mutation frequency of M694V was 4\%. The E148Q mutation of exon 2

Table 1. Restriction enzymes and expected fragment sizes

\begin{tabular}{lcl} 
SNP & $\begin{array}{c}\text { Restriction } \\
\text { Enzyme }\end{array}$ & $\begin{array}{l}\text { Expected DNA } \\
\text { fragments }\end{array}$ \\
\hline M680I & Hinf I & $\begin{array}{l}\text { Wild; } 126 \mathrm{bp}+234 \mathrm{bp} \\
\text { Mutant; } 360 \mathrm{bp}\end{array}$ \\
M694V & Hph I & $\begin{array}{l}\text { Wild; } 195 \mathrm{bp}+23 \mathrm{bp} \\
\text { Mutant; } 218 \mathrm{bp}\end{array}$ \\
M694I & Pag I & $\begin{array}{l}\text { Wild; } 195 \mathrm{bp} \\
\text { Mutant; } 182 \mathrm{bp}+13 \mathrm{bp}\end{array}$ \\
V726A & Alu I & Wild; $360 \mathrm{bp}$ \\
& & Mutant; $320 \mathrm{bp}+40 \mathrm{bp}$
\end{tabular}

SNP: single-nucleotide polymorphism; bp: base pair 
Table 2. Genotype frequencies of rheumatoid arthritis patients and healthy controls

\begin{tabular}{|c|c|c|c|c|}
\hline Genotype & $\begin{array}{l}\text { Patient group } \\
n=110\end{array}$ & $\begin{array}{c}\text { Control group } \\
n=98\end{array}$ & $\begin{array}{c}\text { Genotype frequencies } \\
\text { of patient group }\end{array}$ & $\begin{array}{l}\text { Genotype frequencies } \\
\text { of control group }\end{array}$ \\
\hline \multicolumn{5}{|l|}{ M680I } \\
\hline MM & 107 & 97 & 0.97 & 0.99 \\
\hline MI & 3 & 1 & 0.03 & 0.01 \\
\hline II & 0 & 0 & 0.00 & 0.00 \\
\hline \multicolumn{5}{|l|}{ M694V } \\
\hline MV & 3 & 1 & 0.02 & 0.01 \\
\hline WV & 0 & 0 & 0.00 & 0.00 \\
\hline \multicolumn{5}{|l|}{ M694I } \\
\hline MM & 108 & 95 & 0.98 & 0.97 \\
\hline WV & 103 & 93 & 0.94 & 0.95 \\
\hline VA & 7 & 5 & 0.06 & 0.05 \\
\hline $\mathrm{AA}$ & 0 & 0 & 0.00 & 0.00 \\
\hline
\end{tabular}

Table 3. Statistical results for crosstable of genotype and groups

\begin{tabular}{|c|c|c|c|c|}
\hline Genotype & $\begin{array}{l}\text { Patient group } \\
\quad n=110\end{array}$ & $\begin{array}{c}\text { Control group } \\
n=98\end{array}$ & OR $(95 \% \mathrm{CI})$ & $p$ value \\
\hline \multicolumn{5}{|l|}{ M680I } \\
\hline MM & 107 & 97 & & \\
\hline MI & 3 & 1 & $2.716(0.278-26.583)$ & 0.801 \\
\hline \multicolumn{5}{|l|}{ M694V } \\
\hline MM & 108 & 97 & & \\
\hline \multicolumn{5}{|l|}{ M694I } \\
\hline MM & 108 & 95 & & \\
\hline MI & 2 & 3 & $0.586(0.966-3.584)$ & 0.341 \\
\hline \multicolumn{5}{|l|}{ V726A } \\
\hline
\end{tabular}

OR: odds ratio

was also evaluated, and its mutation rate was reported as $12 \%$. In that study, the total mutation frequency was determined as $17 \%$ in RA patients. One of the striking points was that all of the determined E148Q mutations (12\%) were obtained from female patients. These data are consistent with the earlier finding that females have more risk for RA than males (1). But, these findings are contradicted by the results obtained from another study carried out in parents of FMF patients by Chetrit et al. (13). In this study, parents of FMF patients were found to be homozygously mutated for the E148Q mutation. Interestingly, these mutation carriers have no symptom for FMF. As a result of this study, it was suggested that E148Q mutations were not found to be the cause of FMF disease and inflammation and that this mutation should be considered as a "sequence variant."

In the study of Koca et al. (14) in which RA patients and HC were compared, 8 total mutations were analyzed. The mutation rate of MEFV was defined as $25.2 \%$ and $23.3 \%$ in RA patients and $\mathrm{HC}$, respectively. Interestingly, in that study, mutation rates of E148Q and M694V were higher in HC than RA patients (E148Q RA: $9.7 \%, \mathrm{HC}: 12.6 \%$ and M694V RA: 1.9 , HC: $5.8 \%)$. The reason for the high total frequency of MEFV was the E148Q mutation. In an MEFV mutation screening study of Yilmaz et al. (15) conducted in a Turkish population, like the study of Koca et al. (14), the mutation rate obtained from HC was $2.4 \%$. This value 
was quite low when compared to the value of Koca et al. (14). High MEFV mutation rates in studies by Rabinovich et al. (12) and Koca et al. (14) resulted from E148Q. Mutation rates of M694V, M694I, M680I, and V726A in both studies were close to each other and the current study.

In a previous study conducted in FMF patients in which expression of the MEFV gene was determined, diminished expression of this gene was reported in M694V mutation carrier patients (16). The findings of Ustek et al. (11) were in consistent with the results of Notarnicola et al. (16). In both studies, alteration in the expression of the MEFV gene was investigated in FMF patients in acute attack and attack-free periods. They showed lower mRNA levels of MEFV in blood samples collected during acute attack periods than attack-free periods, which may indicate that a decrement of MEFV gene expression might trigger FMF attacks. The researchers concluded that decreased MEFV expression is related with acute inflammation (11).

Data obtained from this study revealed that there is no remarkable relationship between the M680I, M694V, M694I, and V726A mutations observed in $10^{\text {th }}$ exon of the MEFV gene and RA. Our finding is consistent with the results of two other previous studies $(12,14)$. However, we realized a discrepancy while we compared the results of those studies to each other in terms of the E148Q mutation. Whereas Rabinovich et al. (12) reported a higher $\mathrm{E} 148 \mathrm{Q}$ mutation rate in RA patients than $\mathrm{HC}$, Koca et al. (14) reported a lower rate of this mutation in RA patients.

A limitation of this study is that the numbers of RA patients and $\mathrm{HC}$ could be much higher. In addition, more sensitive techniques, apart from restriction fragment length polymorphism (RFLP) and amplification refractory mutation system (ARMS), could be used.

\section{Conclusion}

In conclusion, although we expected statistically significant results between RA patients and $\mathrm{HC}$ in terms of the M680I, M694V, M694I, and V726A mutations in the design stage of this study, we saw that the MEFV mutation rate between these two groups was slightly different from each other. New research is needed to examine all mutations of the MEFV gene that may affect RA etiopathogenesis.

Ethics Committee Approval: Ethics committee approval was received for this study from the ethics committee of Yüzüncü Yıl University Faculty of Medicine.

Informed Consent: Written informed consent was obtained from patient who participated in this study.

Peer-review: Externally peer-reviewed.

Author Contributions: Concept - H.Ö., I.H.Y., Y.T.; Design H.Ö., L.E.; Supervision - H.Ö., L.E.; Materials - H.Ö., I.H.Y., Y.T.; Data Collection and/or Processing - L.E., V.D., E.G.; Analysis and/ or Interpretation - H.Ö., I.H.Y., Y.T.; Literature Review - H.Ö., I.H.Y.; Writer - H.Ö., I.H.Y.; Critical Review - Y.T., V.D.; Other - V.D., E.G.

Conflict of Interest: No conflict of interest was declared by the authors.
Financial Disclosure: The authors are grateful to the University of Yüzüncü Yıl Grant Commission for providing financial assistance during the tenure of research numbered with $\mathrm{YYU}$ BAP-2010-TF-B020.

Etik Komite Onayı: Bu çalışma için etik komite onayı Yüzüncü Yıl Üniversitesi Tıp Fakültesi'nden alınmıştır.

Hasta Onamı: Yazııı hasta onamı bu çalışmaya katılan hastadan alınmıştır.

Hakem değerlendirmesi: Dış bağımsız.

Yazar Katkıları: Fikir - H.Ö., I.H.Y., Y.T.; Tasarım - H.Ö., L.E.; Denetleme - H.Ö., L.E.; Malzemeler - H.Ö., I.H.Y., Y.T.; Veri toplanması ve/veya işlemesi - L.E., V.D., E.G.; Analiz ve/veya yorum - H.Ö., I.H.Y., Y.T.; Literatür taraması - H.Ö., I.H.Y.; Yazıyı yazan - H.Ö., I.H.Y.; Eleştirel İnceleme - Y.T., V.D.; Diğer - V.D., E.G.

Çıkar Çatışması: Yazarlar çıkar çatışması bildirmemişlerdir.

Finansal Destek: Yazarlar YYU-BAP-2010-TF-B020 numaralı araştırmaya sağladığı finansal destekten dolayı Yüzüncü Yıl Üniversitesi Bilimsel Araştırma Projeleri Başkanlığına teşekkür eder.

\section{References}

1. Mclnnes IB, Schett G. The Pathogenesis of Rheumatoid Arthritis. N Engl J Med 2011;365:2205-19. [CrossRef]

2. Choy EHS, Panayi GS. Cytokine Pathways and Joint Inflammation in Rheumatoid Arthritis. N Engl J Med 2011;344:907-16.

3. Harris ED. Clinical features of rheumatoid arthritis. In: Ruddy $S$, Harris ED, Sledge CB, editors. Kelley's Textbook of Rheumatology. 6th edition, Elsevier, Philadelphia: WB. Saunders Company; 2001.p.967-1000.

4. Cooles FA, Isaacs JD. Pathophysiology of rheumatoid arthritis. Curr Opin Rheumatol 2011;23:233-40. [CrossRef]

5. French FMF Consortium. A candidate gene for familial Mediterranean fever. Nat Genet 1997;1 7:25-31. [CrossRef]

6. Touitou I. The spectrum of Familial Mediterranean Fever (FMF) mutations. Eur J Hum Genet 2001;9:473-83. [CrossRef]

7. McDermott MF. A common pathway in periodic fever syndromes. Trends Immunol 2004;25:457-60. [CrossRef]

8. Centola M, Wood G, Frucht DM, Galon J, Aringer M, Farrell C, et al. The gene for familial Mediterranean fever, MEFV, is expressed in early leukocyte development and is regulated in response to inflammatory mediators. Blood 2000;95:3223-31.

9. Miller SA, Dykes DD, Polesky HF. A simple salting out procedure for extracting DNA from human nucleated cells. Nucleic Acids Res 1988;16:1215. [CrossRef]

10. Booth DR, Lachmann HJ, Gillmore JD, Booth SE, Hawkins PN. Prevalence and significance of the familial Mediterranean fever gene mutation encoding pyrin Q148. QJM 2001;94:527-31. [CrossRef]

11. Ustek D, Ekmekci CG, Selçukbiricik F, Cakiris A, Oku B, Vural B, et al. Association between reduced levels of MEFV Messenger RNA in peripheral blood leukocytes and acute inflammation. Arthritis Rheum 2007;56:345-50. [CrossRef]

12. Rabinovich E, Livneh A, Langevitz P, Brezniak N, Shinar E, Pras M, et al. Severe disease in patients with rheumatoid arthritis carrying a mutation in the Mediterranean fever gene. Ann Rheum Dis 2005;64:1009-14. [CrossRef] 
13. Ben-Chetrit E, Lerer I, Malamud E, Domingo C, Abeliovich D. The E148Q mutation in the MEFV gene: is it a disease-causing mutation or a sequence variant? Hum Mutat 2000;15:385-6. [CrossRef]

14. Koca SS, Etem EO, Isik B, Yuce H, Ozgen M, Dag MS, et al. Prevalence and significance of MEFV gene mutations in a cohort of patients with rheumatoid arthritis. Joint Bone Spine 2010;77:32-5. [CrossRef]
15. Yilmaz E, Ozen S, Balci B, Duzova A, Topaloglu R, Besbas N, et al. Mutation frequency of Familial Mediterranean Fever and evidence for a high carrier rate in the Turkish population. Eur J Hum Genet 2001;9:553-5. [CrossRef]

16. Notarnicola C, Didelot MN, Koné-Paut I, Seguret F, Demaille J, Touitou I. Reduced MEFV messenger RNA expression in patients with familial Mediterranean fever. Arthritis Rheum 2002;46:2785-93. [CrossRef] 